\title{
MENINGKATKAN LITERASI SAINS SISWA KELAS 7 MELALUI PEMBELAJARAN INKUIRI MENGGUNAKAN BAHAN AJAR BERBASIS PROYEK PADA MATERI ENERGI
}

\author{
Fanny Nadia Hardjo ${ }^{*}$, Anna Permanasari ${ }^{2}$, Irvan Permana ${ }^{2}$ \\ ${ }^{1}$ Prodi Pendidikan IPA \\ ${ }^{2}$ Program Pascasarjana Universitas Pakuan Bogor Jawa Barat \\ *Email: Fannynadia99@yahoo.com
}

\begin{abstract}
Abstrak: Penelitian ini bertujuan untuk mengetahui profil pembelajaran inkuiri menggunakan bahan ajar berbasis proyek yang dapat meningkatkan literasi sains siswa pada materi energi. Metode penelitian yang digunakan dalam penelitian ini adalah metode analisis deskriptif. Instrumen yang digunakan dalam penelitian ini terdiri dari lembar angket untuk mengetahui respon siswa dan guru terhadap pembelajaran dan untuk mengetahui peningkatan literasi sains siswa dilakukan tes pilihan ganda berbasis literasi sains. Hasil penelitian menunjukkan bahwa pembelajaran inkuiri dapat meningkatkan literasi sains siswa dengan menggunakan bahan ajar berbasis proyek ditunjukan dengan kenaikan hasil belajar dengan rata-rata pretest sebesar 54, rata-rata posttest sebesar 69 dan $\mathrm{N}$ gain 0,43 (sedang). Bahan ajar berbasis proyek dapat meningkatkan minat siswa dibuktikan dengan hasil tanggapan siswa yang telah melakukan pembelajaran dengan hasil nilai $90 \%$ (sangat baik) dan bahan ajar tersebut dapat memudahkan guru dalam pembelajaran dibuktikan dengan rata-rata tanggapan guru 86\% (sangat baik).
\end{abstract}

Kata Kunci: : Teaching Materials, Inquiry Learning, Scientific Literacy

\section{PENDAHULUAN}

Memasuki abad ke 21 yang semakin pesat, perkembangan pengetahuan maupun teknologi tentunya membutuhkan tantangan sendiri, baik di lingkungan pendidikan maupun dunia kerja saat ini. Oleh karena itu, pendidikan perlu mempersiapkan generasi saat ini dengan keterampilan, baik soft skill maupun hard skill pada setiap tingkatan pendidikan, baik tingkat sekolah dasar sampai perguruan tinggi. Keterampilan-keterampilan penting di abad ke-21 relevan dengan empat pilar kehidupan yang mencakup learning to know, learning to do, learning to be dan learning to live together. Empat prinsip tersebut masingmasing mengandung keterampilan khusus yang perlu diberdayakan dalam kegiatan belajar (Zubaidah, 2016).

Semua keterampilan tersebut sebenarnya terakomodasi dalam kurikulum 2013 yang merupakan kurikulum tematik-integratif dan bertujuan untuk mendorong peserta didik agar mampu lebih baik dalam hal observasi, bertanya, 
bernalar, dan mengkomunikasikan pengetahuan yang diperoleh atau diketahui setelah pembelajaran untuk mencetak generasi yang siap menghadapi masa depan (Permendikbud, 2013). Dalam konteks pendidikan sains, semua tujuan tersebut tercakup dalam literasi sains.

Literasi sains merupakan kompetensi utama dalam mempersiapkan generasi yang mampu menggunakan ilmu pengetahuan dan ilmu informasi untuk berinteraksi dengan tantangan hidup (OECD, 2013). Literasi sains dianggap sebagai akar perubahan progresif pendidikan sains (Sadler \& Zadler, 2009). Menurut Witte (2003), PISA (Programme for International Student Assesment) mendefinisikan literasi sains sebagai kemampuan menggunakan pengetahuan sains, mengidentifikasi permasalahan dan menarik kesimpulan berdasarkan buktibukti, dalam rangka memahami serta membuat keputusan tentang alam dan perubahan yang terjadi pada alam sebagai akibat dari manusia. Pemerintah menetapkan literasi sains sebagai keterampilan generic yang merefleksikan pemahaman masyarakat terhadap kejadian di lingkungan dan fenomena alam, serta hal lainnya yang berhubungan dengan kehidupan. Inilah, mengapa literasi sains bukan hanya milik siswa di sekolah, tetapi bagi orang di luar sekolah pula (Permanasari, 2011).

Uraian di atas menunjukkan arti penting seseorang untuk memiliki literasi sains. Oleh karena itu, perlu adanya tolak ukur untuk seseorang yang literat dalam sains. Program yang mendukung evaluasi literasi sains yaitu PISA merupakan sistem asesmen yang diinisasi oleh Organisation for Economic Cooperation and Development (OECD). PISA telah mengevaluasi sistem pendidikan dari 72 negara di seluruh dunia. Setiap tiga tahun, siswa berusia 15 tahun dipilih secara acak, untuk mengikuti tes dari tiga kompetensi dasar yaitu membaca, matematika dan sains (Kemendikbud, 2016). Dari hasil tes dan evaluasi PISA 2015 performa siswa-siswi Indonesia masih tergolong rendah. Hasil rata-rata skor pencapaian siswa-siswi Indonesia untuk sains, membaca, dan matematika berada di peringkat 62, 61, dan 63 dari 69 negara yang dievaluasi. Peringkat dan rata-rata skor Indonesia tersebut tidak berbeda jauh dengan hasil tes dan survey PISA terdahulu pada tahun 2012 yang juga berada pada kelompok penguasaan materi yang rendah (Iswadi, 2015). Hal ini juga didukung oleh penelitian Ardianto \& Rubini (2014) dari hasil studi tentang literasi sains siswa di Bogor menunjukkan bahwa prestasi literasi sains siswa belum menunjukkan hasil yang memuaskan. Prestasi literasi sains siswa cukup rendah, dengan rata-rata $30 \%$ untuk keseluruhan aspek, yang terdiri dari $29 \%$ untuk konten, $30 \%$ untuk prosesnya, dan $31 \%$ untuk sikapnya.

Menurut Kurnia, dkk (2014) rendahnya kemampuan literasi sains siswa dipengaruhi oleh beberapa faktor, diantaranya kurikulum dan sistem pendidikan, pemilihan metode dan model pembelajaran, sarana dan fasilitas belajar serta sumber belajar. Salah satu model pembelajaran yang sesuai dengan kuirkulum 
2013 yaitu model pembelajaran inkuiri. Model pembelajaran inkuiri adalah kegiatan pembelajaran yang berbasis penyelidikan yang melibatkan siswa dalam sains dan kegiatan berfikir (Weaver et al., 2008).

Salah satu bentuk pendekatan pembelajaran yang menekankan pada pemberian pengalaman langsung dan berpusat pada siswa adalah strategi pembelajaran inkuiri (Meidawati, 2014). Ada berbagai bentuk pembelajaran inkuiri salah satunya dalam penyelidikan, guru memberikan masukan bagi siswa yang memiliki masalah untuk diselidiki bersama dengan prosedur dan materi. Jenis pembelajaran inkuiri ini digunakan untuk mengajarkan konsep, fakta atau keterampilan tertentu dan memfasilitasi cara memulai penyelidikan di mana siswa memformulasikan masalahnya sendiri untuk diselidiki (Abdi, 2014). Selain itu pembelajaran berbasis inkuiri ini tidak semata berorientasi pada hasil pembelajaran semata, tetapi juga menghendaki proses pembelajaran yang bermutu. Disamping model pembelajaran, sumber belajar juga dapat digunakan untuk menunjang kegiatan belajar siswa di kelas dengan menggunakan bahan ajar.

Bahan ajar merupakan alat bantu untuk menyampaikan pesan kepada siswa yang digunakan oleh guru dalam proses belajar. Bahan ajar memudahkan guru dalam menyampaikan materi pembelajaran. Prastowo (2012) menjabarkan bahwa tujuan penggunaan bahan ajar adalah untuk membantu dan memudahkan siswa dalam belajar melalui berbagai macam bentuknya, serta menambah ketertarikan dari kegiatan pembelajaran. Menurut pandangan teori konstruktivisme, kegiatan pembelajaran yang berorientasi pada peserta didik dideskripsikan sebagai pembelajaran dimana peserta didik harus secara aktif membangun pengetahuan sendiri. Model pembelajaran inkuiri dengan menggunakan bahan ajar berbasis proyek dapat mendukung keterlibatan siswa dalam kegiatan pembelajaran. Sehingga pembelajaran ini diharapkan mampu menjembatani keterampilan berpikir dan sikap sains sebagai literasi sains siswa. Oleh karena itu, perlu dilakukan penelitian tentang pembelajaran inkuiri dengan menggunakan bahan ajar berbasis proyek pada materi energi.

\section{METODE}

Metode yang digunakan dalam penelitian ini adalah metode deskriptif analisis. Metode ini digunakan untuk menggambarkan atau menganalisis suatu hasil penelitian (Sugiyono, 2005). Secara singkat langkah-langkah dalam metode penelitian deskriptif, yakni 1) mengidentifikasi adanya permasalahan yang signifikan untuk dipecahkan melalui metode deskriptif; 2) membatasi dan merumuskan permasalahan secara jelas; 3) menentukan tujuan dan manfaat penelitian; 4) melakukan studi pustaka yang berkaitan dengan permasalahan; 5) menentukan kerangka berfikir dan pertanyaan penelitian dan atau hipotesis penelitian; 6) mendesain metode penelitian yang hendak digunakan termasuk 
menentukan populasi, sampel, teknik sampling, instrument pengumpulan data, dan menganalisis data; 7) mengumpulkan, mengorganisasi, dan menganalisis data dengan menggunakan teknik statistik yang relevan; dan 8) membuat laporan penelitian.

\section{HASIL DAN PEMBAHASAN}

Proses pembelajaran dilakukan selama 2 kali pertemuan dilakukan kepada 36 siswa kelas VII. Pembelajaran dilakukan di dalam kelas maupun luar kelas menggunakan model pembelajaran inkuiri dengan mengikuti tugas proyek yang ada pada bahan ajar. Dalam proses pembelajaran, kegiatan inkuiri di tunjang dengan kegiatan proyek berupa pembuatan rangkaian langkah kegiatan untuk membuktikan suatu teori. Pretest diberikan pada siswa sebelum pembelajaran dilakukan, kemudian melaksanakan pembelajaran menggunakan model pembelajaran inkuiri dan bahan ajar. Selama proses pembelajaran siswa memegang secara mandiri bahan ajar yang diberikan guru.

Kegiatan inkuiri yang telah dilakukan didalam kelas dimulai dari guru yang mengorientasikan siswa kepada suatu permasalahan mengenai fenomena energi yang berkaitan dengan pembelajaran. Menurut Abdi (2014) Ketika rangsangan atau stimulus yang diberikan oleh guru bekerja dengan baik, maka dalam pemikiran siswa akan muncul pertanyaan-pertanyaan dan permasalahanpermasalahan yang akan menjadi basis dan tujuan pembelajaran. Kemampuan merumuskan masalah dalam pembelajaran inkuiri sangat penting sebagai titik awal pembelajaran siswa. Pertanyaan dan permasalahan yang baik akan membuat siswa benar-benar belajar, sehingga mereka akan memperoleh pemahaman yang lebih mendalam tentang apa yang sedang dipelajari (Lahadisi, 2014)

Selanjutnya, setelah siswa merumuskan masalah yang ingin dipelajari, mereka kemudian bersama-sama merumuskan hipotesis. Perumusan hipotesis didasarkan pada informasi-informasi yang telah mereka miliki. Hipotesis ini selanjutnya akan diuji kebenarannya. Tetapi terlebih dahulu siswa bersama kelompoknya mengumpulkan sebanyak dan selengkap mungkin data dan informasi yang dibutuhkan. Siswa dan kelompoknya juga memilah-milah informasi dan data mana yang relevan dengan tujuan atau pemecahan masalah mereka. Informasi dan data dikumpulkan dengan beragam metode dan sumber data yang mungkin. Guru bukanlah sumber informasi utama, tetapi lebih berperan sebagai fasilitator sehingga semua kebutuhan siswa dan kelompoknya untuk mengumpulkan data dan informasi yang lengkap dapat berjalan dengan baik. Siswa akan lebih banyak membaca secara mandiri, mengumpulkan bahan-bahan yang dibutuhkan dari bahan ajar dan internet. 
Setelah berkutat dengan beragam sumber belajar yang tersedia dan sumber data yang ada, kemudian siswa melakukan kegiatan eksperimen untuk menguji kebenaran hipotesis yang telah mereka susun dilangkah sebelumnya. Di sini mungkin saja terjadi semacam perbedaan antara informasi yang baru mereka peroleh dengan informasi yang telah mereka miliki sebelumnya. Proses berpikir kreatif, kritis, dan analitis akan dibutuhkan di tahap ini, sehingga mereka dapat menguji hipotesis.

Pada akhir kegiatan pembelajaran, siswa kemudian dapat membuat kesimpulan mereka masing-masing tentang hasil pengujian hipotesis yang telah dilakukan. Proses pembelajaran dengan menggunakan model pembelajaran inkuiri ini memungkinkan siswa mempunyai kedalaman pemahaman akan suatu hal yang mereka pelajari, dan ini terjadi secara kontruktif di mana mereka membangun sendiri pengetahuan baru di atas fondasi pengetahuan yang sebelumnya telah mereka punyai. Hal ini sesuai dengan pendapat Burner dalam Supriyati dan Sri (2007) siswa memiliki pengetahuan apabila menemukan sendiri dan bertanggung jawab atas kegiatan belajarnya sendiri, yang memotivasinya untuk belajar.

Hasil pretest literasi sains pada Tabel 1 menunjukkan bahwa rata-rata nilai hasil literasi sains siswa adalah 54 dan hanya 2,7\% siswa yang dapat mencapai kriteria ketuntasan minimum (KKM) yaitu 75. Hal ini terjadi karena pembelajaran yang biasa dilakukan belum dapat memfasilitasi literasi sains pada kegiatan belajar. Selain itu rendahnya minat membaca siswa dapat menjadi faktor yang mempengaruhi hasil capaian literasi sains siswa. Rata-rata hasil posttest literasi sains siswa meningkat menjadi 69 dengan anak yang mencapai KKM sebanyak $27,7 \%$.

Tabel 1. Hasil Analisis pretest dan posttest Literasi Sains

\begin{tabular}{llll}
\hline No. & Data Implementasi & Pretest & Postest \\
\hline 1. & Jumlah siswa & 36 org & 36 org \\
2. & Rata-rata nilai & 54 & 69 \\
3. & Nilai Tertinggi & 75 & 90 \\
4. & Nilai Terendah & 30 & 50 \\
5. & N-gain & 0.43 (Sedang) \\
6. & \% N-gain & $43 \%$ & \\
\hline
\end{tabular}

Walaupun sedikit meningkat dan rata-ratanya belum melewati KKM tetapi ada peningkatan hasil literasi yang signifikan dari penggunaan bahan ajar. Adapun masing-masing aspek literasi sains disajikan pada gambar 1. Pada aspek konten 
dalam literasi memiliki persentase $74 \%$ dengan kategori baik, untuk aspek keterampilan $69 \%$ dengan kategori baik dan aspek sikap $81 \%$ dengan kategori baik.

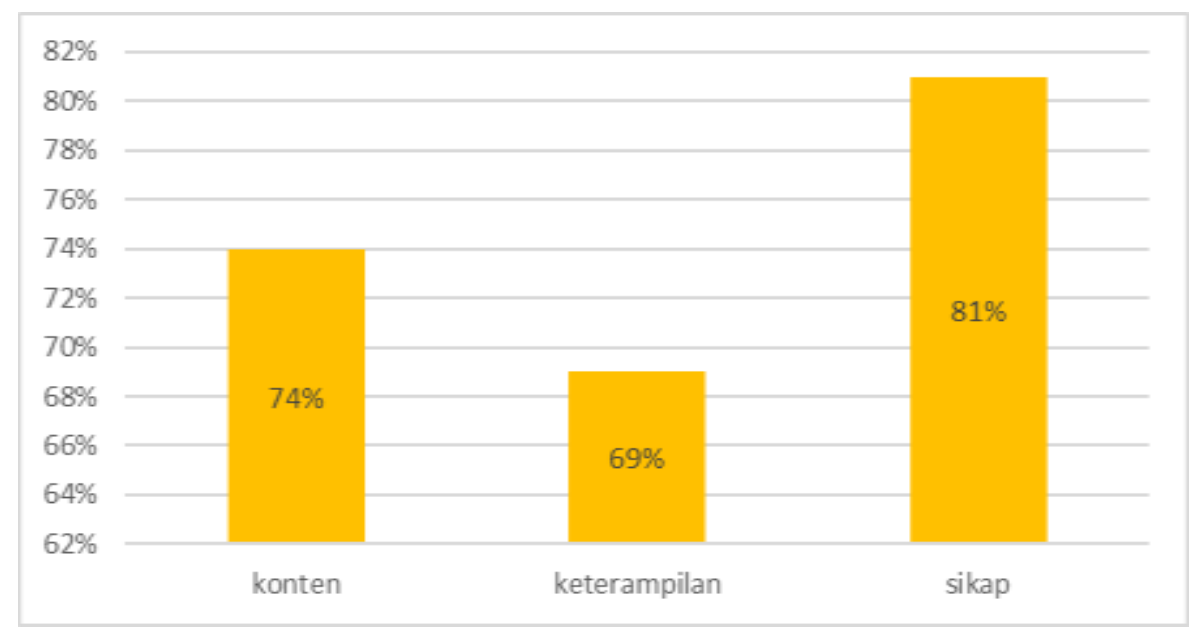

Gambar 1. Hasil Analisis Literasi Sains pada aspek konten, keterampilan dan sikap

Aspek literasi sains siswa sangat penting diketahui untuk mengetahui tingkatan literasi yang telah dicapai siswa. Hal ini didukung oleh Yager dalam Budiningsih (2015) mengatakan guru IPA hendaknya dapat mempersiapkan aspek-aspek literasi sains dalam diri siswa, sehingga siswa memiliki literasi terhadap sains dan teknologi. Literasi sains dapat memberikan pembelajaran yang bermakna bagi siswa. Hal ini didukung dengan pendapat Mayer dan Moreno dalam Latip (2015) yang mengatakan bahwa literasi sains dapat membekali siswa dengan konsep sains yang benar dan membekali siswa agar dapat menerapkan konsep sains pada kehidupan nyata. Karena literasi merupakan kebutuhan penting bagi setiap warga Negara dan sekolah memiliki peranan penting untuk mengembangkan literasi sains siswa (Garthwaite, France, dan ward 2014).

Tanggapan siswa sebagai pemakai bahan ajar perlu diperhatikan. Adapun hasil tanggapan siswa terhadap bahan ajar dengan kategori sangat baik, yaitu sebesar 90\%. Hasil tanggapan siswa dianggap sangat baik dan layak digunakan jika persentasenya diatas 80\% (Arikunto dalam Zain 2013). Hal ini menunjukkan hasil penggunaan bahan ajar pada siswa layak untuk digunakan dalam pembelajaran. Siswa menyukai bahan ajar penuh gambar animasi dan warna. Pada proses pembelajaran siswa sangat antusias dan dapat mengikuti kegiatan proyek dengan baik. Sesuai dengan hasil penelitian Wicaksono (2014) bahwa pembelajaran IPA berbasis proyek dinilai sangat potensial digunakan untuk melatih siswa untuk berpikir, baik secara individu maupun dalam kelompok, serta mencapai hasil belajar yang maksimal. 
Data hasil tanggapan guru terhadap bahan ajar dengan kategori sangat baik yaitu 86\% menurut Arikunto dalam Zain (2013) bahan ajar dikatakan sangat baik jika memiliki nilai > 80\%. Hal ini menunjukkan bahwa pembelajaran yang dilakukan menggunakan bahan ajar dapat menunjang kegiatan yang baik di dalam proses pembelajaran IPA. Guru merasa terbantu oleh adanya model pembelajaran inkuiri yang menggunakan bahan ajar berbasis proyek karena memudahkan proses pembelajaran dan merasa semua kegiatan pembelajaran sudah ada dalam kegiatan model pembelajaran maupun bahan ajar mulai dari materi, kegiatan eksperimen, rangkuman sampai pada tes formatif sebagai alat evaluasi akhir. Model pembelajaran inkuiri dan bahan ajar berbasis proyek dianggap dapat meningkatkan capaian siswa dalam belajar. Hal ini sesuai dengan pernyataan yang disampaikan Anni (2004), bahwa kesiapan, proses dan hasil belajar dipengaruhi oleh kondisi internal dan kondisi eksternal pembelajar. Penerapan metode baru dalam pembelajaran akan memberikan hasil yang optimal bila kondisi internal siswa dalam keadaan baik dan memiliki kesiapan yang baik untuk melaksanakan kegiatan pembelajaran.

\section{PENUTUP}

Berdasarkan pembahasasan di atas, dapat disimpulkan bahwa bahan ajar berbasis proyek dapat mendukung upaya peningkatan literasi sains siswa, baik pada aspek konten, keterampilan dan sikap siswa terhadap sains. Siswa memberikan tanggapan positif terhadap penggunaan bahan ajar berbasis proyek dalam pembelajaran inkuiri.

\section{REFERENSI}

Abdi, A. (2014). The Effect of Inquiry-based Learning Method on Students' Academic Achievement in Science Course. Universal Journal of Educational Research, 2(1): 37-41

Anni, C.T. (2004). Psikologi Belajar. Semarang: UNNES.

Ardianto, D dan Rubini, B. 2014. Analisis Literasi Sains Sisiwa di Kota Bogor. Research Report. Bogor: Pascasarjana Universitas Pakuan.

Budiningsih, T.Y. Rusilowati, A. Marwoto P. (2015). Pengembangan Buku Ajar IPA Terpadu Berorientasi Literasi Sains Materi Energi Dan Suhu. Tesis. Program Pascasarjana: Universitas Negeri Semarang.

Garthwaite, K., France, B., Ward, G. (2014). The Complexity of Scientific Literacy: The development and use o data analysis matrix. International Journal of Science Education, 36(10), 1568-1567.

Iswadi, Hazrul. (2015). Sekelumit dari Hasil PISA 2015 yang Baru dirilis. Diakses dari http://www.ubaya.ac.id/2014/content/articles_detail/230/ Sekelumit-Dari-Hasil-PISA-2015-Yang-Baru-Dirilis.html. 
Kemendikbud. 2016. Peringkat dan Capaian PISA Indonesia Mengalami Peningkatan. Diakses dari https://www.kemdikbud.go.id/main/blog/2016/12/peringkat-dan-capaianpisa-indonesia-mengalami-peningkatan.

Kurnia, Zulherman \& Fathurohman. (2014). Analisis Bahan Ajar Fisika SMA Kelas XI di Kecamatan Indralaya Utara Berdasarkan Kategori Literasi Sains. Jurnal Inovasi dan Pembelajaran Fisika, 1(1), 43-47.

Lahadisi. (2014). Inkuiri: Sebuah Strategi Menuju Pembelajaran Bermakna. Jurnal Al-Ta'dib, 7(2).

Latip, A \& Permanasari, A. (2015). Pengembangan Multimedia Pembelajaran Berbasis Literasi Sains untuk Siswa Smp Pada Tema Teknologi. Jurnal Edusains. Diakses dari http://journal.uinjkt.ac.id/index.php/edusains

Meidawati, Yenni. (2014). Pengaruh Pendekatan Pembelajaran Inkuiri Terbimbing Terhadap Peningkatan Kemampuan Pemecahan Masalah Matematis Siswa SMP. Jurnal Pendidikan dan Keguruan, 1(2)

OECD. (2013). What students know and can do -student performance in mathematics, reading and science (volume 1). Diakses dari http://www.oecd.org/ pisa/keyfindings/pisa-2012-results-volume-I.pdf

Permanasari, A. (2011). Pembelajaran Sains: Wahana potensial untuk membelajarkan soft skill dan karakter. Seminar nasional pendidikan IPA di Universitas Lampung.

Permendikbud. (2013). Implementasi Kurikulum 2013. Jakarta: Kementrian Pendidikan dan Kebudayaan.

Prastowo, A. (2012). Panduan Kreatif Membuat Bahan Ajar Inovatif. Yogyakarta: DIVA Press.

Sadler, T.D dan Zeidler, D.L. (2009). Scientific Literacy, PISA, and Socioscientific Discourse: Asessment for Progressive Aims of Science Education. Journal of science Teaching, 1(1), 1-13.

Sugiyono. (2005). Memahami Penelitian Kualitatif. Bandung: Alfabeta.

Supriyati, Y \& Sri, A.W. (2007). Strategi Pembelajaran Fisika.Jakarta. Universitas Terbuka.

Weaver, G., Russell, C., \& Wink, D. (2008). Inquiry-based and research-based laboratory pedagogies in undergraduate science. Nature Chemical Biology, $4(10), 577-580$.

Wicaksono, I. (2014). Pengembangan Modul Ipa Berbasis Proyek Untuk Meningkatkan Kemandirian Belajar Dan Hasil Belajar Siswa Smp. Tesis. Program Pascasarjana: Universitas Negeri Yogyakarta.

Witte, D. dan Beers, K. 2003. Testing Of Chemical Literacy (Chemistry In Context In Dutch National Examination). Chemical Education International Journal. 4(1), 1-3

Zain, N.H. (2013). Pengembangan Komik Bahan Ajar IPA terpadu Kelas VIII SMP Pada Tema Sistem Pencernaan Manusia dan Hubungannya dengan Kesehatan. Skripsi Program Studi Pendidikan IPA. Fakultas Matematika dan Ilmu Pengetahuan Alam. Universitas Negeri Semarang. 
Zubaidah, S. (2016). Keterampilan Abad Ke-21: Keterampilan Yang Diajarkan Melalui Pembelajaran. Universitas Negeri Malang. 